\title{
BULAS INQUISITORIAIS: AD ABOLENDAM (1184) E VERGENTIS IN SENIUM (1 199)*
}

\author{
Leandro Duarte Rust
}

Universidade Federal de Mato Grosso

\begin{abstract}
Resumo mentos para pesquisa.

Pallavras-Chave

documentos medievais $\bullet$ bulas inquisitoriais $\bullet$ história política.
\end{abstract}

Neste trabalho apresentamos numa tradução bilíngue, latim-português, dois importantes documentos medievais, as decretais Ad Abolendam (1184) e Vergentis in Senium (1199). Usualmente qualificadas como "textos fundadores da Inquisição", essas bulas são documentos valiosos do cenário político de fins do século XII. A tradução, inédita em língua portuguesa, é acompanhada de breve texto introdutório e alguns aponta-

\section{Contato:}

Universidade Federal de Mato Grosso

Departamento de História

Av. Fernando Corrêa da Costa, $\mathrm{n}^{\circ} 2.367$

78060-900 - Cuiabá - MT

E-mail: leandrorust@yahoo.com.br.

* Esta pesquisa contou com o apoio do CNPq. Prezado leitor: todas as citações realizadas e que emergem neste texto desacompanhadas de referências integram os textos traduzidos ao final. Agradeço, imensamente, ao Professor Doutor José Antônio de Camargo Rodrigues de Souza pela minuciosa revisão destas traduções. Se o diabo está nos detalhes, como diz o velho ditado popular inglês, devo dizer que este pequeno trabalho foi "exorcizado" pelo professor José Antônio. 


\title{
INQUISITORIAL BULLS: AD ABOLENDAM (1184) AND VERGENTIS IN SENIUM (1199)
}

Leandro Duarte Rust

Universidade Federal de Mato Grosso

\begin{abstract}
In this paper we present two important medieval documents, the decretals Ad Abolendam (1184) and Vergentis in Senium (1199), in a bilingual edition, Latin-Portuguese. Usually described as "the founding texts of the Inquisition", these bulls record the political scene at the end of the $12^{\text {th }}$ century. Unpublished in Portuguese, the translation comes to public with a brief introductory text and some notes for historical information. Keywords

medieval documents $\bullet$ inquisitorial bulls $\bullet$ political history.
\end{abstract}

\section{Contact:}

Universidade Federal de Mato Grosso

Departamento de História

Av. Fernando Corrêa da Costa, $n^{\circ} 2.367$

78060-900 - Cuiabá - MT

E-mail: leandrorust@yahoo.com.br. 
A vitória não amanheceu em triunfo. Foi o que descobriu o pontífice Lúcio III com o passar dos anos. Após duas longas e penosas décadas de conflito, a paz selada entre o Papado e o Império na cidade de Veneza, nos idos de 1177, não calou as contestações lançadas contra o Trono de Pedro. Na ocasião, Frederico I finalmente curvou sua recusa de mais de vinte anos e reconheceu Alexandre III como legítimo papa. Mas o gesto não embalou qualquer atitude de rendição da corte teutônica. Sete anos transcorreram e o Hohenstaufen continuou a pressionar e a perturbar o Papado com demandas que sobressaltavam o espírito de Lúcio, escolhido pelos cardeais como sucessor de Alexandre. ${ }^{1}$

No Lácio, tudo em redor da Sé Romana persistia ameaçador. Os exílios de Alexandre, sucessivamente empurrado para longe pelo inclemente conflito com o Império, abriram caminho para a afirmação de um governo comunal almejado em Roma há décadas. Quando retornou de suas prolongadas ausências, o pontífice encontrou a "Cidade dos Apóstolos" regida por agudo anticlericalismo. Encurralado pela oposição romana, ele se viu completamente dependente daquele que fora até então o seu maior adversário, Frederico I. Para chegar à basílica de São Pedro e ao Palácio Lateranense, o séquito papal teve de ser escoltado por Cristiano, arcebispo de Mainz. A Cúria permaneceu em Roma enquanto o odiado arcebispo, homem de armas dos Hohenstaufen, fez jus à terrível reputação de "criminoso" (nefarii) e se pôs a "difundir muitos males". ${ }^{2}$ Cristiano ateou suas tropas sobre as áreas vizinhas e aterrorizou os cinturões rurais da Cidade Eterna

\footnotetext{
1 A Paz de Veneza deixou inconclusa uma questão de primeira ordem para a política papal: a reivindicação imperial da herança patrimonial deixada pela Condessa Matilde, que incluía áreas extensas e estratégicas no norte peninsular. Após sua eleição em 1181, Lúcio recusou todas as ofertas para o reconhecimento da legítima posse imperial das terras matildinas, desgastando seriamente as relações com o monarca "Barba Ruiva". Além disso, o entendimento entre eles era ainda dificultado pela resistência papal em consentir com as solicitações imperiais de uma ampla aprovação pontifícia para a investidura de bispos germânicos, ocorridas durante o cisma vivido por Alexandre III. Neste sentido, é possível afirmar que ao longo dos anos as recusas de Lúcio foram tomando a forma de uma política anti-imperial: ROBINSON, Ian Stuart. The Papacy: 1073-1198. Cambridge: Cambridge University Press, 1990, p. 497-503. Ver ainda: PARTNER, Peter. The Lands of St Peter: the papal state in the middle ages and the early renaissance. Londres: Methuen, 1972, p. 171-245; WALEY, Daniel. The Papal State in the Thirteenth Century. Londres: MacMillan \& Co., 1961, p. 5-22.

2 Christianus cancellarius imperatoris Frederici, qui multa mala Tuscis intulit. ANNALES PISANI. MGH SS 19: 265. Em outras palavras, a permanência de Alexandre em Roma dependia das mesmas ações que seus partidários até então condenavam veementemente como responsáveis pelos "dias terriveis" do cisma. A Vita Alexander III Papae até então apontava a violência das campanhas imperiais empreendidas na península como o sopro de uma destruição quase inigualável que tornou insustentável a estadia do papa no Lácio. O texto evoca a ferocidade das tropas germânicas como causa que intimidou os espíritos até então fiéis à autoridade petrina. CARDEAL BOSO. Vita Alexander III. Liber Pontificalis 2: 414.
} 
com constantes ataques e pilhagens. Graças à proteção assim obtida, o papa pôde reunir um concílio na basílica de São João de Latrão, em março de 1179. Mas, quando as intrigas locais levaram à captura de Cristiano, lançando-o em cativeiro por longo tempo, Alexandre teve de deixar Roma uma vez mais e faleceu, em exílio, em agosto de $1181 .^{3}$

O pacto de 1177 dera à luz uma paz machucada, franzina. Desde então, Lúcio via seus receios se multiplicarem, ceifando as esperanças semeadas pela reconciliação com o Império. As incertezas ferviam o juízo daquele prelado experiente, calejado por mais de trinta anos de cardinalato. A vitória de seu antecessor era uma promessa de segurança que teimava em não concretizar-se por inteiro. Ele esperava por definições que pareciam desaguar na impotência. Desde a saída de Roma, a Cúria perambulava pela península: todo seu governo seria vivido no exílio, em Velletri, Anagni e, por fim, Verona. O próprio Frederico I tirou proveito da visível dependência política da Sé Apostólica, ao transformar a estadia do Papado nesta última cidade em um conveniente confinamento. Arfando sua vulnerabilidade, Lúcio tornou-se refém das garantias estendidas pelo imperador, que soube penhorar seu apoio como um meio de manter o séquito pontifício em Verona, sob atenta vigilância e privado de livres comunicações com a Cristandade. ${ }^{4}$

Acuado naquelas cidades, o papa se viu ainda rodeado por outro perigo: a "heresia". Dominado por paisagens dinâmicas, que sobejavam em riquezas e em circulação de homens e ideias, o norte peninsular tornou-se palco de intensas transformações sociais e projetou novos grupos laicos. O exílio forçou Lúcio a travar um face a face com a nova realidade de práticas, ideias e aspirações fomentadas pelos agudos contrastes sociais urbanos, comumente arredios aos preceitos hierárquicos da eclesiologia papal. ${ }^{5}$ À medida que o tempo passava tais grupos se insinuavam cada vez mais nos quadros das elites senhoriais. Enraizavam sua presença nos espaços públicos, nos postos de autoridade. ${ }^{6}$ Suas pregações e seu

MUNZ, Peter. Frederick Barbarossa: a study in medieval politics. Ithaca: Cornell University Press, 1969, p. 363.

4 ZERBI, Piero. Un inedito dell Archivio Vaticano e il Convegno di Verona. Aevum, n. 28, 1954, p. 470-48. Ver ainda: FIGUEIRA, Robert C. (Ed.). The Plenitude of Power: the doctrines and exercise of authority in the Middle Ages - essays in memory of Robert Louis Benson. Aldershot: Ashgate, 2006, p. 38; BOLTON, Brenda; DUGGAN, Anne J. (Org.). Adrian IV: the english pope (1154-1159). Aldershot: Ashgate, 2003, p. 135-137.

5 DEAN, Trevor. The Towns of Italy in the Later Middle Ages. Manchester: Manchester University Press, 2000, p. 68-75; ABULAFIA, David. Italy in the Central Middle Ages: 1000-1300. Oxford: Oxford University Press, 2004, p. 9-12; CAMERON, Euan. Waldenses: rejections of holy church in medieval Europe. Oxford: Blackwell, 2000, p. 37-48.

${ }^{6}$ LANSING, Carol. Power \& Purity: Cathar heresy in medieval Italy. Oxford: Oxford University 
modo de vida deixavam em difícil situação a obediência à autoridade apostólica. Vendo-se no limiar de um nevoeiro de fraquezas, Lúcio aferrou-se à sua voz de legislador e em 4 de novembro de 1184 anunciou um conjunto de instruções contra os hereges. ${ }^{7} \mathrm{O}$ texto, proclamado diante do plenário eclesiástico reunido em Verona, ficou conhecido entre os historiadores como a bula Ad Abolendam. É o primeiro documento aqui traduzido em versão bilíngue.

Suas palavras depositavam nos bispos as prerrogativas de erradicação da "depravação das heresias": tudo o que dizia respeito à missão de localizar, corrigir e punir os violadores da unidade cristã estaria atrelado ao juízo daqueles prelados. Duas vezes por ano caberia a eles percorrer as paróquias e desentocar "todos que não receiam sentir ou ensinar algo distinto do que a sacrossanta igreja romana prega e observa". Segundo a bula, os procedimentos de investigação e punição pertenciam à jurisdição dos bispados. Portanto, a Ad Abolendam pode ser considerada o registro de uma característica que costumamos recobrir com esquecimento: os procedimentos judiciais (inquisitiones) estabelecidos por ela foram instituídos pelo Papado, mas estavam politicamente constituídos como uma instituição episcopal. Por conseguinte, formavam uma descentralizada e intricada rede de poderes particulares e interesses locais. Tal autonomia não desapareceria nas décadas seguintes. A história inquisitorial seguiu marcada pelas fortes tensões oriundas desta articulação de diferentes instâncias decisórias, desta junção de lideranças amiúde divergentes, como demonstraram Henry Charles Lea, Mariano Alatri, Edward Peters, James Buchanan Given e Michael Thomsett. ${ }^{8}$ Em páginas referenciais, John Tedeschi advertiu: "the Inquisition, far from being a monolithic

Press, 1998, p. 11; MILLER, Maureen Catherine. The Bishop's Palace: architeture \& authority in medieval Italy. Ithaca: Cornell University Press, 2000, p. 164-165.

7 FRIEDBERG, Emil (Ed.). Corpus Iuris Canonici: pars secunda Decretalium Collectiones. Graz: Akademische Druck-U. Verlagsanstalt, 1959, p. 780-782. E ainda: HEFELE, Charles Joseph; LECLERCQ, Henry. Histoire des Conciles aprés les documents originaux. Paris: Letouzey et Ané, 1912-1915, tomo 5/2, p. 1087-1095, p. 1116-1127; WATTERICH, Johann Matthias. (Ed.). Pontificum Romanorum Vitae qui fuerunt inde ab exeunte saeculo IX usque ad finem saeculi XIII. Leipzig: 1860-1862, vol. 2, p. 658.

8 LEA, Henry Charles. A History of the Inquisition of the Middle Ages. Londres: Harper \& Brothers, 1887, p. 1-23; ALATRI, Mariano. Eretici e inquisitori in Italia: studi e documenti. Brindisi: Collegio San Lorenzo da Brindisi, Istituto Storico dei Cappuccini, 1987, v. 1, p. 125; PETERS, Edward. Heresy and authority in medieval Europe: documents in translation. Philadelphia: University of Pennsylvania Press, 1980, p. 189; GIVEN, James B. Inquisition and Medieval Society: power, discipline \& resistance in Languedoc. Ithaca/Londres: Cornell University Press, 1997; THOMSETT, Michael C. The Inquisition: a history. Jefferson: McFarland \& Co., 2010, p. 11-16. 
structure, was an institution which experienced development and change, in terms of organization, procedures and definitions of the law".

O austero texto proclamado por Lúcio impressiona. Não sem razão; afinal, tratava-se de um filho pródigo do racionalismo letrado do século XII. Herdeiro de dezenas de cânones anti-heréticos presentes no Decretum de Graciano ${ }^{10}$ e das medidas proclamadas por Alexandre III nos Concílios de Tours (1163) e de Latrão (1179), ${ }^{11}$ seu texto enrijeceu as medidas relativas à denúncia, à excomunhão e ao confisco de bens dos "claramente surpreendidos em heresia".

Com linguagem áspera, a bula declarou sanções não somente contra a heresia em si, mas direcionadas a um espectro maior de comportamentos dissidentes. Não bastava endireitar uns poucos espíritos desviantes. Era preciso desbaratar o nicho que os abrigava, arrancar em toda extensão as raízes de sua "insolência e falsidade". Por isso as penas canônicas deveriam recair também sobre os "acolhedores e protetores, todos que de alguma forma oferecem apoio ou favor aos mencionados hereges", e a classificação como herege deveria tingir todos que se negassem a jurar o que fosse exigido pelo arbítrio do bispo.

Imbuída dos rigores da razão letrada, a bula ganhou outra singularidade: ela não se limitou a identificar os acusados de heresia de maneira genérica, referindo-se a eles como uma indistinta massa de transgressores. A Ad Abolendam os distinguiu em grupos, enumerando-os nominalmente como "Cátaros, Patarinos, os Humilhados ou Pobres de Lyon, Passaginos, Josefinos e Arnaldistas". Ela declinou as identidades heréticas. Porém, ao embaralhá-las na mesma condenação seu texto revestiu a política papal com uma aparente coerência, fazendo ver uma rejeição

9 TEDESCHI, John. Preliminary Observations on Writing a History of the Roman Inquisition. In: CHURCH, F. F. \& GEORGE, Timothy (Ed.). Continuity and Discontinuity in Church History. Leiden: Brill, 1979, p. 239.

${ }^{10}$ Cabe ressaltar que o próprio Decretum sintetizava uma longeva trajetória de elaborações canônicas, incluindo o Decretum de Burchard de Worms, o Panormia de Ivo de Chartres, a Collectio Canonum do cardeal Deusdedit e o texto homônimo de Anselmo de Lucca. GALLAGHER, Clarence. Canon Law and the Christian Community. Roma: Università Gregoriana Editrice, 1978, p. 185; WINROTH, Anders. The Making of Gratian's "Decretum". Cambridge: Cambridge University Press, 2000, p. 34-78.

${ }^{11}$ Sobre a Assembleia Eclesiástica de Tours: CARDEAL BOSO. Vita Alexander III. Liber Pontificalis 2: 407-412; FRIEDBERG, Emil (Ed.). Quinque Compilationes Antiquae. Leipzig: Bernhard Tauschnitz, 1882, p. 56. Ver ainda: SOMERVILLE, Robert. Pope Alexander III and the Council of Tours. Los Angeles: University of California Press, 1977. Sobre o Concílio de Latrão: MANSI, Johannes D. (Ed.). Sacrorum Conciliorum Nova et Amplissima Collectio. Graz: Akademische Druck, 1961, tomo 22, col. 217-223; HEFELE, Charles Joseph; LECLERCQ, Henry. Histoire des Conciles aprés les documents originaux. Paris: Letouzey et Ané, 1912-1915, tomo 5/2, p. 1087-1095 ; FOREVILLE, Raymonde. Lateranense I, II y III. Vitoria: Eset, 1972, p. 172-294; LONGĖRE, Jean. Le Troisième Concile de Latran (1179): sa place dans l'histoire. Paris: Études Augustiniennes, 1982. 
integral e inflexível lá onde havia constantes oscilações das atitudes perante estes mesmos grupos, por vezes tolerados e noutras até mesmo encorajados. ${ }^{12}$ Esta atenção às funções representativas dos nomes dos grupos heréticos, somada à promulgação da bula em um ambiente sinodal - como uma constituição não apenas do papa, mas do conjunto da Igreja romana, reunido em assembleia -, consolidou uma importante inflexão jurídica: impôs a plena categorização legal da heresia como crime capital e público, razão suficiente para legitimar diversas ações de marginalização e expropriação dos acusados, antes mesmo da formalização das sentenças. Como relembrou Frances Andrews, a autoridade pontifícia delineou os nomes heréticos de modo a torná-los categorias através das quais as consciências comunitárias cristãs deveriam reconhecer a identidade do desvio, do esfacelamento do pertencimento coletivo, enfim, do alheamento à identidade religiosa então partilhada. ${ }^{13}$ Estas e outras características justificariam a reputação deste documento como tendo sido, à época, "the most elaborate juridical statement concerning the treatment of heretics made to that date by the Latin Church". ${ }^{14}$

Todavia, é preciso não se deixar seduzir pela rispidez e firmeza da linguagem papal. Como indicamos nas páginas acima, a virulência das palavras de Lúcio III não deve ofuscar a preocupante realidade que enchia suas entrelinhas, impregnando-as de limitações políticas e de uma vulnerabilidade inquietante.

A Ad Abolendam ganhou contornos em meio ao cerceamento do governo papal, que só repousava quando se acomodava nas dobras da hegemonia imperial.

${ }^{12}$ Sobre as a trajetória do conceito de "cátaros" e seu controverso emprego por parte dos historiadores ver: MACEDO, José Rivair. Heresia, Cruzada e Inquisição na França Medieval. Porto Alegre: EDPUCRS, 2000. A Ad Abolendam é diretamente responsável por converter o nome "Patarino" em sinônimo de "Cátaro", algo para o qual não se tem registros documentais precedentes. Ao fazê-lo, ela imprimiu inequívoca classificação herética a um movimento ao qual o papado esteve estritamente associado durante o século XI, inclusive como aliado imprescindível na realização da assim chamada "Reforma Papal". HAMILTON, Janet; HAMILTON, Sarah; HAMILTON, Bernard (Eds.). Hugh Eteriano: Contra Patarenos. Leiden: Brill, 2004, p. 9-10. Sequer é preciso examinar a aplicação ou a vigência da Ad Abolendam para reconhecer, como indicou Jennifer Kolpacoff Deane, que o próprio texto da bula de 1184 acabava por implicar em repercussões diversas para os grupos mencionados, tal era o caso de, por exemplo, os "Catáros" e os "Valdenses". Ver: DEANE, Jennifer Kolpacoff. A History of Medieval Heresy and Inquisition. Lanham: Rowman \& Littlefield Co., 2011, p. 68. Uma opinião divergente é apresentada em: FRASSETTO, Michael. Heretic Lives: medieval heresy from Bogomil and the Cathars to Wyclif and Hus. Londres: Profile Books, 2007, p. 67-71.

${ }^{13}$ ANDREWS, Frances. Self-representation in time of crisis: the case of early Humiliati. In: MÜLLER, Anne; STÖBER, Karen (Eds.). Self-Representation of Medieval Religious Communities. Berlim: LIT Verlag Münster, 2009, p. 221; ANDREWS, Frances. The Early Humiliati. Cambridge: Cambridge University Press, 1999, p. 38-98.

${ }^{14}$ PETERS, Edward. Inquisition. Berkeley/Los Angeles: University of California Press, 1989, p. 48. 
É preciso dar ouvidos a Lúcio e à declaração, gravada no próprio documento, de que ele e seu séquito se encontravam "sustentados com a força de nosso filho caríssimo, Frederico, ilustre imperador dos romanos, sempre augusto". Tais palavras foram mais do que fórmula de estilo ou deferência retórica: neste caso, elas podem ser tomadas como verdadeira avaliação política. Portanto, talvez seja o momento de dar razão a Peter Diehl e reconhecer o ríspido texto de 1184 como um "diploma imperial" tanto quanto uma bula - futuramente uma decretal - e não um documento papal em sentido estrito ${ }^{15}$ As referências ao imperador não seriam alusões a um "auxiliar", um mero "protetor" ou "colaborador" recrutado para aplicar as sanções estipuladas. Personificados na figura de Frederico I, os poderes seculares evocados na bula não estariam limitados ao subordinado papel de "braço secular" da abolição das heresias, como afirmou R. H. Helmholz em estudo notável. ${ }^{16} \mathrm{~A}$ Ad Abolendam emergia da autoridade imperial, seu texto expressa a interpenetração medieval dos poderes temporal e espiritual. Tratava-se, por assim dizer, de uma "bula do imperador", não exclusivamente do pontífice: um "estatuto simultaneamente imperial e eclesiástico".

Aliás, quando nos voltamos para os domínios temporais do Papado - o Patrimônio de São Pedro -, constatamos sua flagrante incapacidade em fazer valer a decretal de 1184. Os sucessores de Lúcio zelaram por sua incorporação na primeira grande coletânea de decretais, conhecida como Compilatio I e composta por Bernardo de Pávia entre 1188 e $1192 ;{ }^{17}$ mas seu fracasso em alojá-la nos domínios efetivos da política era retumbante, como demonstra o caso sintomático apresentado a seguir.

Entrincheirada num formidável sítio militar, Orvieto foi a primeira comuna italiana da qual se teve notícias da presença dos cátaros, expressamente condenados pela Ad Abolendam. Logo no início de seu pontificado, em abril de 1198,

\footnotetext{
${ }^{15}$ DIEHL, Peter. Ad abolendam (X 5.7.9) and Imperial Legislation against Heresy. Bulletin of Medieval Canon Law, vol. 19, 1989, p. 1-11.

${ }^{16}$ HELMHOLZ, R. H. The Spirit of Classical Canon Law. Athens: University of Georgia Press, 1996, p. 363. Diferentemente de Helmolz, chegamos à perspectiva de que a vinculação do documento à autoridade de Frederico I, somada às circunstâncias de sua promulgação, atuaram como uma formalização da Ad Abolendam como um texto oficialmente vigente como uma lei imperial: razão pela qual recorremos à improvável expressão "diploma imperial", embora saibamos que tal caracterização seja incompatível tanto com os princípios técnicos como com os jurídicos da usual classificação documental aplicada aos resquícios escritos do período.

${ }^{17}$ FRIEDBERG, Emil (Ed.). Quinque Compilationes Antiquae. Leipzig: Bernhard Tauschnitz, 1882, p. 226. Ver ainda: MÜLLER, Wolfgang; SOMMAR, Mary (Eds.). Medieval Church Law and the Origins of the Western Legal Tradition. Washington: Catholic University of America Press, 2006, p. 154-158.
} 
Inocêncio III pôs a cidade sob interdito. Embora fosse cada vez mais frequente, a medida era drástica, pois consistia na "formalização coletiva da máxima culpa", segundo a afortunada expressão cunhada por Peter Clarke..$^{18}$ Os "ofícios divinos" deveriam cessar; missas, sermões e horas canônicas deveriam ser suspensos; os templos permaneceriam fechados; os sacramentos celebrados em segredo, quando muito. ${ }^{19}$ A punição deveria dissuadir as lideranças citadinas de sua reivindicação sobre Aquapendente, fortaleza estratégica para o Papado, persuadindo-as a obedecer. ${ }^{20}$ Mas a proclamação agiu em outra direção: acendeu os sentimentos de desprezo pela hierarquia clerical, minando a já tênue obediência devida pelos habitantes ao poder eclesiástico local, malvisto por muitos como um agente dos interesses romanos. Desgastada por uma sucessão de embates envolvendo bispos, cônegos regulares, aristocratas e a própria comuna desde os anos 1150, a autoridade episcopal perdeu força, seus aliados recuaram. ${ }^{21}$ Acossado por tantos impasses, Ricardo, então bispo de Orvieto, deixou a diocese e se refugiou na Cúria. Sua ausência cedeu espaço ao "catarismo", atraindo pregadores heréticos de localidades vizinhas, como Viterbo, outra sede política do Patrimônio de São Pedro.

Com a cidade ainda sob interdito, Inocêncio enviou o senador romano Pietro Parenzo. Em fevereiro de 1199, encarregou-o de restaurar a ordem política e dar cabo dos hereges. O pontífice fiava-se pelas instruções de seu antecessor, agarrava-se às orientações de Lúcio III: como rector da cidade, o enviado deveria recompor a

${ }^{18}$ CLARKE, Peter. The Interdict in the Thirteenth Century. Oxford: Oxford University Press, 2007. ${ }^{19}$ KREHBIEL, Edward. The Interdict: its history and its operations. Washington: AHA, 1909, p. 15-74. Ver ainda o útil estudo: CONRAN, Edward J. The Interdict. Washington: The Catholic University of America, 1930.

${ }^{20}$ Embora a fortaleza de Aquapendente tenha sido o estopim do agravamento das tensões entre a Sé Apostólica e a comuna de Orvieto, certamente, é apropriado situar a interdição imposta por Inocêncio III em quadro maior de medidas anti-heréticas pontifícias, que incluíam as decretais Mirari Cogimur et (16 de abril de 1198) Cum unus Dominus (21 de abril de 1198): POTTHAST, n. 82, 95. Ver ainda: VACANDARD, Elphège. The Inquisition: A Critical and Historical Study of the Coercive Power of the Church. Fairford: Echo Library, 2010, p. 36.

${ }^{21}$ LAMBERT, Malcolm D. The Cathars. Oxford: Blackwell Publishing, 1998, p. 92-95; LANSING, Carol. Power \& Purity: Cathar heresy in medieval Italy. Oxford: Oxford University Press, 1998, p. 25-41; LANSING, Carol. Passion and Order: restraint of grief in the medieval Italian communes. Ithaca: Cornell University Press, 2008, p. 25-97, 228-243; LOOS, Milan. Dualist Heresy in the Middle Ages. Praga: s/e., 1974, p. 279; WALEY, Daniel. Mediaeval Orvieto: the political history of an Italian city-state, 1157-1334. Cambridge: Cambridge University Press, 1952, p. 11-15. Como demonstrou Augustine Thompson, o "catarismo" teve ampla difusão nas comunas da Itália setentrional, indicador de que os grupos classificados como heréticos estavam efetivamente inseridos nos quadros das elites locais, implicados nas disputas sobre o controle dos espaços públicos e a constituição dos governos comunais. THOMPSON, Augustine. Cities of God: the religion of the Italian communes, 1125-1325. University Park: The Pennsylvania State University Press, 2005, p. 141-234. 
autoridade episcopal e garantir o livre curso dos procedimentos da inquisitio. Mas sua esperança logo minguou. Em maio, Parenzo foi emboscado e encerrou quatro agitados meses de governo sangrando até a morte em um casebre entrouxado junto aos portões da cidade. Embora a causa pontifícia tenha encontrado um mártir cultuado em meio a uma generosa multiplicação de relatos sobre milagres - "this loss of authority over heresy and the evident failure of Ad Abolendam produced in Italy a state very like crisis by the end of the century". ${ }^{22} \mathrm{O}$ sangrento desfecho era igualmente efeito da instabilidade imperial: a repressão pontifícia à heresia carecia de seu sustentáculo político, então enfraquecido por uma inclemente guerra sucessória, deflagrada pela morte de Henrique VI - filho de Frederico I - dois anos antes. Dilacerada por conflitos internos, a hegemonia imperial fraquejava, revelando-se incapaz de impulsionar seus exércitos e ministeriales para além dos Alpes, sobre a península italiana e as cidades do Patrimônio de São Pedro.

Antes mesmo do assassinato, Inocêncio descobriu-se desarmado perante a difusão das heresias no Patrimônio Petrino e, como seus antecessores, sentiu sua autoridade desnudar-se. Era preciso, uma vez mais, vestir o pesado manto das leis canônicas. Foi então, no dia 25 de março de 1199, que o papa ditou a decretal Vergentis in Senium, a segunda bula inquisitorial aqui traduzida.

Dirigida aos magistrados de Viterbo, ${ }^{23}$ outra cidade papal povoada pelo crescimento da presença catára, a nova bula tem um início peculiar. Como uma homilia, ela entoa um tom pastoral carregado de marcas da educação de Inocêncio. ${ }^{24}$ Suas primeiras linhas concebem a proliferação das heresias como efeito do "envelhecimento do mundo". Segundo a decretal, se a dissidência crescia, ganhando contornos ainda mais apavorantes, era por que a decrepitude humana avançara ao seu último estágio, apoderando-se por completo dos corações cris-

\footnotetext{
${ }^{22}$ LAMBERT, Malcolm. Medieval heresy: popular movements from the Gregorian reform to the Reformation. Oxford: Blackwell Publishing, 2002, p. 90; VINCENZO, Natalini (Ed.). S. Pietro Parenzo: la leggenda scritta dal Maestro Giovanni canonico di Orvieto. Roma: Facultas Theologica Pontificii Athenaei Seminarii Romani, 1936; MACCARRONE, Michele. Studi su Innocenzo III. Pádua: Antenore, 1972, p. 30-51; WAUGH, Scott; DIEHL, Peter (Eds.). Christendom and Its Discontents: exclusion, persecution, and rebellion, 1000-1500. Cambridge: Cambridge University Press, 1996, p. 22-25.

${ }_{23}$ POTTHAST, Augustus (Ed.). Regesta Pontificum Romanorum inde ab a. post Christum natum MCXCVIII ad a. MCCCIV. Berlin: Academia Litterarum Berolinensi, 1874-1875, n. 643.

${ }^{24}$ Toda a bula é marcada por uma linguagem pastoral característica do círculo eclesiástico formado em Paris, em redor da figura de Pedro, o Cantor. Círculo que inclúa Inocêncio III e os cardeais Robert de Courson e Estevão de Langton. Ver o clássico estudo: BALDWIN, John. Masters, Princes, and Merchants: the social views of Peter the Chanter \& his circle. Princeton: Princeton University Press, 1970, vol. 1.
} 
tãos, contaminando a todos. Pois a "semente dos iníquos recobre a colheita do Senhor" quando a fé está em frangalhos, corroída pela macabra decadência das criaturas, perdidas em seu decrépito apego às coisas vãs. A vida estaria podre e sua decomposição permitiria aos pecados e vícios se espalharem sem peia, manchando as almas, arrastando-as para o abismo dos erros. Estes temas, típicos de uma longínqua tradição letrada associada ao ideal do Contemptus Mundi (Desprezo pelo Mundo), estavam frescos na pena e na memória papais. Afinal, cerca de cinco anos antes, quando era ainda um jovem cardeal, Inocêncio transpôs noites debruçado sobre aqueles pensamentos lúgubres, que reuniu no ilustre opúsculo De contemptu mundi sive de miseria conditionis humanae. ${ }^{25}$

Contudo, esse pessimismo estava longe de se resumir a uma convenção de estilos ou inspiração de fervor pastoral. Ele era alimentado por fracassos políticos. A própria Vergentis registrou a ineficácia das medidas anti-heréticas até então proclamadas pela Sé Romana. Em seu texto o papa derramou seu lamento: "diversos predecessores nossos divulgaram medidas em diferentes ocasiões, mas não a ponto de aniquilar as pestes mortíferas, sobretudo contra este câncer que se espalhou amplamente de modo oculto e que agora derrama abertamente a iniquidade de seu veneno". A imagem do mundo sucumbindo a tantas "formas farsescas de religião" feria a consciência de Inocêncio como um espinheiro, verrumando-lhe na cabeça a dura certeza de testemunhar o ocaso da autoridade clerical. O fantasma da impotência política assombrava-o com a ideia de "ser chamado de cachorro mudo, incapaz de latir" contra as "raposas que estão destruindo a vinha do Senhor", segundo as palavras da própria bula. ${ }^{26}$

Tentando cravar um fim naquela luta sem descanso, o Papado fez do novo texto uma confirmação prática das regras estabelecidas pela Ad Abolendam e atuou como continuador direto das decisões outrora proclamadas por Lúcio III,

\footnotetext{
${ }^{25}$ LOTÁRIO DI SEGNI. De Contemptus Mundi sive De Miseria Conditionis Humanae. PL vol. 217, col. 703-737; ARCHTERFELDT, Johannes (Ed.). Innocentii III De Contemptus Mundi. Bonn: Eduard Weber, 1855. A tradição literária do Contemptus Mundi era constituída por um descentrado e longevo universo de escritos, em especial, oriundos dos claustros medievais. Ver: HOWARD, Donald R. The Three Temptations: medieval man in search of the World. Princeton: Princeton University Press, 1966, p. 56-160. O opúsculo de Inocêncio III alcançou grande fortuna manuscrita e tornou-se um modelo consagrado para a retórica da "tristeza do finito", em especial para o período renascentista e as escolas neoplatônicas, como demonstra: DELUMEAU, Jean. O Pecado e o Medo: a culpabilização no Ocidente (séculos 13-18). Bauru: EDUSC, 2003, vol. 1, p. 19-160.

${ }^{26}$ KENDAL, Keith. 'Mute Dogs, Unable to Bark': Innocent III's call to combat heresy. In: MÜLLER, Wolfgang; SOMMAR, Mary (Eds.). Medieval Church Law and the Origins of the Legal Western Tradition. Washington: The Catholic University of America Press, 2006, p. 170-178.
} 
como notaram Brenda Bolton e James B. Given. ${ }^{27}$ Entretanto, a Sé Apostólica foi além. Ela reavivou uma severa categoria do antigo direito dos Césares: a noção do "crime de lesa majestade". Na realidade, o conceito de laesum maiestas era bem conhecido pelos eclesiásticos do século XII familiarizados com os textos canônicos e as tradicionais fórmulas de glorificação do poder monárquico. Formulado pela Lex Quisquis, redigida por ordem dos imperadores Honório e Acádio, em 4 de setembro de $397,{ }^{28}$ o conceito era mencionado pelo Concílio de Calcedônia (451), ${ }^{29}$ pelos Annales Regni Francorum (863?), ${ }^{30}$ constava em notórias epístolas atribuídas ao papa João VIII $(875)^{31}$ e a Fulberto de Chartres (1020?), ${ }^{32}$ no fragmento de uma constitutio do imperador Henrique

${ }^{27}$ BOLTON, Brenda. Tradition and Temerity: papal attitudes to deviants, 1159-1216. In: BAKER, Derek (Ed.). Schism, Heresy and Religious Protest. Cambridge: Cambridge University Press, 1972, p. 79-92; GIVEN, James Buchanan. Inquisition and medieval society: power, discipline, and resistance in Languedoc. Ithaca: Cornell University Press, 1998, p. 13.

${ }^{28}$ Como tal a noção figurava no Codex Justinianus: "Quisquis cum militibus vel privatis barbaris etiam scelestam inierit factionem aut factionis ipsius susceperit sacramenta vel dederit, de nece etiam virorum illustrium qui consiliis et consistorio nostro intersunt, senatorum etiam (nam et ipsi pars corporis nostri sunt), cuiuslibet postremo qui nobis militat cogitarit (eadem enim severitate voluntatem sceleris qua effectum puniri iura voluerunt), ipse quidem utpote maiestatis reus gladio feriatur, bonis eius omnibus fisco nostro addictis: Arcad. et Honor. aa. eutychiano pp. a $397 \mathrm{~d}$. prid. non. sept. ancyrae caesario et attico conss". In: KRUEGER, Paulus. Corpus Iuris Civilis: volumen secundum, codex. Berlim: Weidmannos, 1889, vol. 2, 9.8.5. Ainda: BAUMANN, R. A. Some Problems of the Lex Quisquis. Antichthon, vol. 1, 1967, p. 49-59.

${ }^{29}$ Neste caso nos reportamos ao cânone 18, cujo texto proibia a realização de conjurações contra os membros da hierarquia eclesiástica: "Conjurationis vel sodalitatis crimen ab externis etiam legibus est omnino prohibitum; multo autem magis hoc in Dei Ecclesia fieri prohibere oportet. Si qui ergo Clerici vel Monachi inventi fuerint, vel conjurati, vel sodalitates comparantes, vel aliquid struentes adversus Episcopos aut Clericos proprio graduo omnino excident". CHALCEDONENSIS CONCILII. MANSI, Johannes D. (Ed.). Sacrorum Conciliorum Nova et Amplissima Collectio. Graz: Akademische Druck, 1961, tomo 7, col. 366.

${ }^{30}$ Neste caso trata-se da descrição de um pronunciamento do papa Leão III logo após a coroação imperial de Carlos Magno: "Post paucos autem dies iussit eos, qui pontificem anno superiore deposuerunt, exhiberi; et habita de eis questione secundum legem Romanam ut maiestatis rei capitis dampnati sunt". ANNALES FULDENSIS SIVE ANNALES REGNI FRANCORUM ORIENTALIS. MGH SS rer. Germ., tomo 7, p. 15. E ainda: NOBLE, Thomas F. X. The Republic of St. Peter: the birth of the Papal State, 680-825. Philadelphia: University of Pennsylvania Press, 1991, p. 294.

${ }^{31}$ Trata-se da carta enviada aos habitantes de Nápoles, Salerno e Amalfi com o propósito de dissuadi-los de uma aliança com os sarracenos: "Cum enim regis rebellionibus quocumque particípio coniunguntur, pariter maiestatis criminibus obnoxii iudicantur, parique sententia condemnantur; quantum a corpore Christi probantur extranei, qui eius hostibus federati, membra ipsius tanto perniciosius lacerant, quanto5 vicinius ecclesie Dei colliminant?” JOÃO VIII. Epistola 53. MGH Epp., tomo 7, p. 306.

${ }^{32}$ A epístola em questão é direcionada ao conde Fulque de Nera e a passagem relevante consiste em suas linhas iniciais: Tam horrendo facinore praesentiam domini regis tui dedecoravere satellites, ut mundani iudices asserant capitale te quoque reum maiestatis qui eis postea patrocinium tuum et receptacula praebuisti. FULBERTO DE CHARTRES. Epistola 95. PL vol. 141, col. 246. 
III (1052?) de grande circulação no século XI ${ }^{33}$ além de ocupar espaço de destaque no Decretum de Ivo de Chartres (1094? $)^{34}$ e no de Graciano (1140). ${ }^{35}$

Segundo Inocêncio III, os condenados por heresia deveriam ser declarados "culpados pelo delito de lesa majestade". Eles carregariam as marcas da alta traição, que não necessitava chegar às raias da conspiração para ser revelada: a perfídia estava na sombra da infidelidade, bastava ser considerado desleal à autoridade clerical para ser culpado de contrariar a "divina majestade de Jesus Cristo". A heresia deveria ser vista, de uma vez por todas, como "crime de desobediência". Quem não estivesse de acordo com a Sé Romana não poderia ser considerado catholicus. Ao amparar-se nesta premissa, a Vergentis reascendeu um princípio presente no Dictatus Papae (1075?), de Gregório VII, relação à qual Othmar Haegeneder dedicou páginas memoráveis. ${ }^{36}$

A condenação como herege provaria a infâmia do acusado, que estaria sujeito à pena de excomunhão e ao confisco de seu patrimônio. Seus filhos partilhariam o mesmo infortúnio, suportando a privação de bens e a interdição a qualquer ofício público, pois a ignomínia dos genitores estaria impregnada em suas carnes, como se a heresia fosse uma essência impura que corresse em suas veias. ${ }^{37}$ Conforme as próprias palavras papais: "segundo o juízo divino, também os filhos sofrem

\footnotetext{
${ }^{33} \mathrm{O}$ fragmento contém o que segue: "Heinricus divina pietate secundus Romanorum imperator augustus omnibus decet imperialem solertiam contemptorem suae praesentiae capitali dampnare sententia”. CONSTITUTIO DE CONTEMPTORIBUS IMPERATORIS. MGH Const., tomo 1, p. 102. Este fragmento seria veiculado por Wipo, Anselmo de Besate e Benzo de Alba, alcançando grande notoriedade entre os propagandista imperiais de fins do século XI. Ver: ROBINSON, Ian Stuart. Authority and Resistance in the Investiture Contest: the polemical literature of the late eleventh century. Nova York: Manchester University Press, 1978, p. 81-82.

${ }^{34}$ Neste caso trata-se do capítulo 90 do décimo primeiro livro, no qual é reproduzida a epístola do papa João VIII. IVO DE CHARTRES. Decretum. PL, vol. 161, col. 775. Ver ainda: ROLKER, Christof. Canon Law and the Letters of Ivo of Chartres. Cambridge: Cambridge University Press, 2009, p. 54-57.

${ }^{35}$ Sane quisquis hanc sanctam et uenerandam antistitis sedem pecuniae interuentu subisse, aut si quis, ut alterum ordinaret uel eligeret, aliquid accepisse detegitur, ad instar publici criminis et lesae maiestatis accusatione proposita, a gradu sacerdotis retrahatur. Nec hoc solum deinceps honore priuari, sed perpetuae quoque infamiae dampnari decernimus, ut e facinus quos par coinquinat et equat, utrosque similis pena comitetur. FRIEDBERG, Emil (Ed.). Corpus Iuris Canonici: pars prior Decretum Magistri Gratiani. Graz: Akademische Druck-U. Verlagsanstalt, 1959, parte secunda, causa XV, q. III, c. VI p. 752.

${ }^{36}$ Tratava-se do capítulo 26 do memorandum papal ditado por Gregório, provavelmente, em 1075. DICTATUS PAPAE. MGH Epp. sel. , p. 203. Ver ainda: HAGENEDER, Othmar. Il Sole e la Luna:Papato, impero e regni nella teoria e nella prassi dei secoli XII e XIII. Milão: Vita e Pensiero, 2000, p. 213-234.

${ }^{37}$ CHIFFOLEAU, Jacques. Sur le crime de majesté medieval. In : GENET, Jean-Philippe (Ed.). Genèse de l'Etat moderne en Méditerranée. Rome, Collection de l'Ecole française de Rome, 1993, p. 183-313.
} 
(...) por seus pais e (...) o castigo recai não apenas sobre os autores dos crimes, mas também sobre a descendência dos condenados". A falha dos pais deixou-os desprovidos da "herança divina": por que haveriam de manter a herança terrena?

Ratione Peccati. O herético estava poluído pelo pecado e as falhas que habitavam seu peito eram altamente contagiosas. Sua "depravação" derramava-se como uma mancha de óleo sobre tudo o que ele tocava: bens, ofícios, negócios, testemunhos, escrita. Era preciso arrancá-lo do convívio cristão e purgar tudo que carregava os traços de sua nefasta presença: terras, prerrogativas, objetos, pergaminhos. Se fosse mercador, seus negócios não gerariam qualquer obrigação. Se juiz, suas sentenças seriam nulas e seu tribunal maldito de toda maneira. Caso se tratasse de um notário, os registros lavrados por ele seriam inválidos. Legislando "em razão do pecado", a Vergentis coroou a heresia como causa jurídica suficiente para justificar amplas intervenções nos espaços considerados públicos e nas relações de poder e autoridade. Foi o que ocorreu nos anos seguintes, quando o Papado ditou medidas de supressão da autonomia de "cidades heréticas" no interior do Patrimônio de São Pedro ${ }^{38}$ e ofereceu o amplo perdão da indulgência aos que tomaram parte da violenta conquista senhorial no Languedoc a partir de 1209, a chamada "cruzada albigense". 39

Diferentemente da Ad Abolendam, a bula inocenciana não contava com o respaldo de um plenário conciliar. Seu texto era um digno representante da tradição epistolar dos séculos XI e XII: era uma orientação conferida a um caso pontual, circunstancial. Porém, seu alcance histórico não foi menor do que o da bula promulgada por Lúcio III: ambas foram tratadas pela tradição canônica posterior como documentos igualmente fundadores, detentoras das regras a serem seguidas nos procedimentos públicos de repressão à heresia e à dissidência cristã. De fato, as duas bulas figuram lado a lado nas coleções documentais que conferiram sustentação normativa e legitimidade jurisdicional às posteriores ações dos Tribunais do Santo Ofício, como demonstra a edição do Bulario de

\footnotetext{
${ }^{38}$ WEBB, Diana. The Church and Sovereignty c.590-1918: essays in honour of Michael Wilks. Cambridge: Publ. Blackwell, 1991, p. 139-141. Ver ainda: BOLTON, Brenda. Innocent III: studies on papal authority and pastoral care. Aldershot: Ashgate Publishing, 1995, n. III, p. 208; GAULIN, Jean-Louis et alii (Dir.). Villes d'Italie: textes et documents des XIIe, XIIIe et XIVe siècles. Lyon: Presses Universitaires de Lyon, 2005, p. 136.

${ }^{39}$ HAGENEDER, Othmar. Il Sole e la Luna... op. cit., p. 149-153. Vale aqui lembrar a célebre epístola com a qual os legados no Languedoc justficaram ao papa a elevação de Simon de Montfort a "príncipe" daquelas terras em razão de sua liderança na "supressão das heresias": MILO \& ARNALDO AMAURY. Epistola. PL 216: 137-141.
} 
la Inquisición Española hasta la muerte de Fernando el Católico, realizada por Gonzalo Martínez Díez. ${ }^{40}$

Tais características têm feito os historiadores insistirem na reputação da Vergentis in Senium como um feito de importância inigualável. Seu aparecimento foi "the major step in the formalization of the persecution of heretics" já realizado pelo Papado, segundo a avaliação de Edward Peters. ${ }^{41}$ Suas linhas decretaram "la fine del lungo periodo di disorientamento e d'indecisione da parte della gerarchia", afirmaram Franco Cardini e Marina Montesano. ${ }^{42}$ Recentemente Ruth Karras referiu-se a ela como uma das razões que fizeram do governo de Inocêncio III um divisor de águas na compreensão cristã da relação entre a lei e a ilicitude. ${ }^{43}$ Opinião que parece seguir de perto a análise realizada por Laura Baietto há duas décadas: "la Vergentis segnò un momento significativo nella costruzione di una societas christiana intesa in senso unitario, a prescindere dalle distinzioni laico-ecclesiastico". ${ }^{44}$ Maurice Bévenot viu na bula razão para localizar o pontificado inocenciano como marco fundador da Inquisição. ${ }^{45}$ Opinião assim arrematada por Kenneth Pennington: "until the persecution of heresy fell into desuetude in the eighteenth century, the law of heresy was governed by the stark provisions of Vergentis" ${ }^{4} 6$

Entretanto, seria um equívoco tratar a Vergentis in Senium como uma "criação papal", o "inovador fruto" de uma racionalidade governamental estritamente pontifícia. Ao contrário do que sugeriu o seminal The Significance of Innocent III's Decretal Vergentis, publicado por Walter Ullmann na década de $1960,{ }^{47}$ a bula inocenciana não foi um ponto de ruptura ou de "re-orientação" das práticas repres-

${ }^{40}$ MARTÍNEZ DÍEZ, Gonzalo. Bulario de la Inquisición Española hasta la muerte de Fernando el Católico. Madrid: Editorial Complutense, 1997.

${ }^{41}$ PETERS, Edward. Inquisition... op. cit., p. 48.

${ }^{42}$ CARDINI, Franco; MONTESANO, Marina. La Lunga Storia dell'Inquisizione: luci e ombre della "leggenda nera". Roma: Città Nuova, 2007, p. 19.

${ }^{43}$ KARRAS, Ruth Mazo et alii (Ed.). Law and the Illicit in medieval Europe. Philadelphia: University of Pennsylvania Press, 2008, p. 13.

${ }^{44}$ BAIETTO, Laura. Il Papa e le Città: papato e comuni in Italia centro-settentrionale secolo XIII. Clio, vol. 21, 1985, p. 345-393.

${ }^{45}$ BÉVENOT, Maurice. The Inquisition and its antecedents III. Heythrop Journal, vol. 8, n. 1, 1967, p. 52-69. Ver ainda: FICHTENAU, Heinrich. Heretics and Scholars in the Middle Ages: 1000-1200. Philadelphia: The Pennsylvania State University Press, 1998, p. 148.

${ }^{46}$ PENNINGTON, Kenneth. "Pro Peccatis Patrum Puniri": A Moral and Legal Problem of the Inquisition. Church History, vol. 47, 1978, p. 137-154, neste caso a citação deriva da p. 137. Ver: PENNINGTON, Kenneth; EICHBAUER, Melodie Harris (Orgs.). Law as Profession and Practice in Medieval Europe: essays in honor of James A. Brundage. Farnham: Ashgate Publishing, 2011, p. 41-48.

${ }^{47}$ ULLMANN, Walter. The Significence of Innocent III's Decretal Vergentis. Études d'histoire du droit canonique dédiées à Gabriel Le Bras. Paris: Sirey, 1965, vol. 1, p. 729-742. 
soras medievais. O argumento pode soar estranho, talvez absurdo ou "apologético" para alguns, mas essa bula pode ser considerada um mecanismo de refreamento da violência socialmente difundida, ao invés de um vetor de agravamento da opressão manejada pelas instituições. Vejamos um exemplo.

A fórmula do laesa maiestatis já havia sido aplicada sobre acusados de heresia antes de Inocêncio ordenar que ela fosse entregue ao pergaminho. Em outubro de 1194, Afonso II de Aragão sacou-a contra os valdenses e demais hereges durante as celebrações do sínodo de Lleida. Sem surtir o efeito desejado, a decisão foi confirmada pelo sucessor no trono, Pedro II, em fevereiro de 1198, na assembleia de Gerona. ${ }^{48}$ Nas duas ocasiões, a coroa fortaleceu sua posição ordenando sanções ainda mais severas do que o Papado: as medidas já indicadas pela Ad Abolendam vieram acompanhadas de ordens de expulsão do reino, a concessão de amplos favores régios aos delatores da heresia e a ordem para que os corpos dos condenados fossem queimados (corpora eorum ignibus crementur $).^{49}$ No âmbito da política papal, ações como estas eram abafadas pela ênfase depositada sobre o confisco de patrimônio e o banimento de ofícios como punições anti-heréticas. A prioridade destas penas tornou-se empecilho prático para aplicação de sentenças letais. Como bem ressaltou Peter Clarke, no raiar do século XIII, a lei canônica não estipulava a morte para o expurgo da culpa. ${ }^{50}$ Embora evocassem as bulas papais como os textos instauradores de sua ação repressora, aqueles monarcas ibéricos não se limitavam a acatar suas disposições. Ao

\footnotetext{
${ }^{48}$ GONNET, Giovani. Enchiridion Fontium Valdensium. Torre Pellice: Ed. Claudiana, 1958, vol. 1, p. 92; Edicto antiherético promulgado por el rey de Aragón Alfonso el Trovador contra valdenses, pobres de Lyon y otros herejes. In: MARQUÈS, Jaume. Alfonso II, el Casto, y la Seo de Gerona. VII Congreso de Historia de la Corona de Aragón. Barcelona: Vda. de Fidel Rodríguez, 1962, tomo II, p. 207-222; ALVIRA CABRER, Martín. Pedro el Católico, Rey de Aragón y Conde de Barcelona (1196-1213): documentos, testimonios y memoria histórica. Zaragoza: C.S.I.C., tomo I, p. 265 (Fuentes Históricas Aragonesas 52).

${ }^{49}$ BARAUT, Cebriá. Els inicis de la inquisició a Catalunya i les seves actuacions al bisbat d'Urgell (segles XII-XIII). Urgellia: Anuari d'estudis històrics dels antics comtats de Cerdanya, Urgell i Pallars, d'Andorra i la Vall d'Aran, n. 13, 1996-1997, p. 407-438. Ver igualmente: ALVIRA CABRER, Martín. El cuerpo derrotado: cómo trataban musulmanes y cristianos a los enemigos vencidos (Peninsula Ibérica, siglos VIII-XIII). Madrid: C.S.I.C, 2008, p. 249-256; GASCÓN $\mathrm{CHOPO}$, Carles. La carta de Niquinta y la Ecclesia Aranensis: una reflexión sobre los orígenes del catarismo en Catanluña. Espacio, Tiempo y Forma, serie 3, tomo 21, 2008, p. 139-158; SMITH, Damian J. Innocent III and the crown of Aragon. Aldershot: Ashgate Publishing, 2004, p. 33-36; SMITH, Damian. Crusade, Heresy and Inquisition in the Lands of the Crown of Aragon, c. 1167-1276. Leiden: Brill, 2010, p. 91.

${ }^{50}$ CLARKE, Peter. Innocen III, Canon Law and the Punishment of the Guiltness. In: MOORE, John C.; BOLTON, Brenda et alii (Ed.). Pope Innocent and His World. Aldershot: Ashgate Publishing, p. $272-285$.
} 
contrário, eles as aplicavam de maneira autônoma, superavam-nas, excediam-nas, subordinavam-nas a dinâmicas jurídicas diversas, a realidades políticas em que o lugar de instância decisória não estava ocupado pelo poder pontifício.

O exemplo aragonês - um entre muitos possíveis - realça a descentralização medieval das práticas inquisitoriais e, simultaneamente, age como uma ferroada em nossa recorrente postura de tratar estas bulas como fontes de um sistema normativo. Afinal, nós historiadores, teimamos em enquadrá-las neste modelo de ordem jurídica firmado pelo constitucionalismo do século XIX. Agimos assim toda vez que olhamos para as decretais papais e julgamos ver as linhas de forças que permitem deduzir o vasto quadro do direito daquela época, como se os comportamentos sociais, em sua amplitude, estivessem ligados aos princípios gerais contidos nestas páginas, de onde emanaria certa unidade jurídica essencial. ${ }^{51}$ Nesta perspectiva, a Ad Abolendam e a Vergentis in Senium são encaradas como pontos aos quais a realidade deveria permanecer acorrentada. Bastaria tomar suas normas como verdadeiro farol histórico, como o vértice em função do qual os poderes medievais traçariam a extensão da legalidade e o mais-além da ilicitude. ${ }^{52}$

Tal atitude retrata a imensa dívida intelectual que temos com os constitucionalistas e sua fervorosa "paixão pelas leis", que elevou o texto jurídico ao patamar de instituidor da vida social, exaltando-o como plataforma de fundação das condutas e decisões coletivas. Não sem razão esta imagem das leis como os eixos de grandes afrescos históricos tem nos atraído há décadas ao reconfortar nossa racionalidade científica: "o monismo jurídico oferece vantagens e autoriza o repouso das certezas: o que pode ser mais tranquilizador que um astro único num céu fixo?"53

Os textos aqui traduzidos pertenciam a um irredutível ambiente de pluralismo jurídico. As bulas apresentadas nas páginas seguintes estavam situadas nos cruzamentos de múltiplas ordens jurídicas, atravessadas por diversos parâmetros de normatização. Esses documentos da história inquisitorial não eram as chaves

\footnotetext{
${ }^{51}$ GOYARD-FABRE, Simone. Os Fundamentos da Ordem Jurídica. São Paulo: Martins Fontes, 2007, p. 113.

${ }^{52}$ Sob este olhar, os preceitos escritos figuram como imperativos de conduta, e qualquer desvio ou inobservância a seu respeito significaria, para os agentes históricos, violação ou grave distúrbio. Interpretação que advém de um modo de pensar proveniente do século XIX e dos códigos legais elaborados sob inspiração do positivismo jurídico. Entendimento frequentemente sugerido por estudos de grande relevância historiográfica e inegável capacidade erudita: PIERGIOVANNI, Vito. La punibilità degli innocenti nel diritto canonico dell'età classica. Milão: Giuffrè, 1971-1974, 2 vol.; PENNINGTON, Kenneth. Popes, Canonists and Texts, 1150-1550. Londres: Variorum, 1993; MAISONNEUVE, Henri. Le droit romain et la doctrine inquisitoriale. In: Études d'histoire du droit canonique dédiées à Gabriel Le Bras. Paris: Sirey, 1965, p. 931-942.

${ }^{53}$ ROULAND, Norbert. Nos Confins do Direito. São Paulo: Martins Fontes, 2008, p. 159.
} 
lógicas da ordem legal dos séculos XII e XIII, mas algumas de suas muitas partes: fragmentos de uma época juridicamente descentrada e distante da uniformização institucional. ${ }^{54}$ No que tange ao período em questão, é preciso reconhecer que os textos canônicos, embora cristalizassem o racionalismo das universidades medievais, frequentemente figuravam como confins da ordem jurídica existente, não como "o cerne" que a estruturava. Entre eles e a concretização da prática legal havia um longo e contraditório caminho a ser percorrido pelas elites senhoriais, impondo sobre situações idênticas àquelas mencionadas nos textos das bulas a legítima incidência de mecanismos jurídicos diferentes, díspares. Por conseguinte, incorremos em certos abusos quando pressupomos que as relações entre as formulas textuais e a efetiva decisão jurídica estariam calcadas na linearidade ou mesmo em alguma transposição direta.

A bula de 1199 foi rapidamente difundida pela Igreja Romana, que em menos de cinco anos garantiu sua presença no Languedoc e em cortes cristãs de Aragão até a Hungria. ${ }^{55}$ Mas a política anti-herética registrada em suas linhas a precedia: o regime repressor expressado por ela jamais esteve dado na própria letra da lei, ele a ultrapassava como uma densa e dispersa nuvem de poderes locais, não como um governo unitário e coeso irradiado por um "centro" sobre o mundo cristão. Em suma, um ângulo de observação cada vez mais promissor para o estudo de documentos como a Ad Abolendam e a Vergentis in Senium parece ser o de tratá-los como mediadores sociais, que, como tal, devem ter seu significado histórico avaliado à luz da incidência de diversos outros fatores juridicamente decisivos, quiçá proeminentes em relação às lógicas das práticas escriturísticas. Se ainda sentimos desconforto perante esta proposição, talvez isso se deva ao

\footnotetext{
${ }^{54}$ MESCHINI, Marco. L'evoluzione della normativa antiereticale di Innocenzo III dalla Vergentis in Senium (1199) al IV concilio lateranense (1215). Bullettino dell'Istituto Storico Italiano per il Medio Evo, n. 106, vol. 2, 2004, p. 207-231; MESCHINI, Marco. Validità, novità e carattere della decretale "Vergentis in senium" di Innocenzo III (25 marzo 1199). Bulletin of Medieval Canon Law, n. 25, 2002/2003, p. 94-113.

${ }^{55}$ Em 1200 a bula foi enviada a Giovanni São Paulo, cardeal presbítero de Sancta Prisca e legado no Languedoc, para instruir a luta contra os cátaros: POTTHAST, n. 1092; THOUZELLIER, Christine. Catharisme et Valdéisme em Languedoc à la fin du XIIe siècle et au début du XIIIe siècle. Paris: PUF, 1966, p. 156. Em outubro do mesmo ano seu texto foi integrado à correspondência destinada a Emerico, rei da Hungria, exortando-o a expulsar de suas terras o banus Culin de Bosnia, reputado como protetor dos hereges bogomilos: INNOCÊNCIO III. Epistola 3.5. PL vol. 214, col. 872. Em 1203, a bula foi endereçada à rainha Sancha de Aragão: CABRER, Martín Alvira; SMITH, Damian. Política Antiherética en la corona de Aragón: una carta inédita de Inocencio III a la Reina Sancha. Acta Historica Archaeologica Mediaevalia, n. 27-28, 2006, p. 65-88.
} 
velho hábito de permanecer impressionados pela tenebrosa grandeza histórica reputada às inquisições.

"Inquisição". Aí está um nome refém de uma lenda negra ainda hoje alimentada pelo pensamento liberal. ${ }^{56}$ São poucos os que o pronunciam sem deixar a voz cair num tom tétrico ou o semblante ser carregado por um ar grave. Mais raros ainda os que deixam de sentir um respeito reverencial pelos conceitos atrelados a ele. Nós, historiadores, costumamos enxergá-lo como a marca de crimes quase impronunciáveis, uma chaga de obscurantismos, o funesto privilégio de uma herança acima de tudo católica e ibérica. ${ }^{57}$ Reconhecer e condenar esta "agência de segregação e sofrimento" figura em nossa cultura acadêmica como um hábito intelectual tanto quanto um dever moral.

Porém, há quase um século esta imagem enraizada tem sido alvo de valiosos esforços de revisão crítica, ${ }^{58}$ graças aos quais pudemos perceber que as inquisições não foram criações alheias à vida social comum, como se tivessem sido instrumentos de um terror excepcional, chamado à vida por instituições triunfantes e imposto "dos pináculos do poder" sobre o tecido do convívio coletivo. As práticas inquisitoriais medievais não eram tentáculos de uma esfera majestática superior, que desfigurava as relações sociais para melhor dominá-las do alto, de fora. Não. Elas decorriam de vastos movimentos sociológicos, resultavam

${ }^{56}$ MORENO MARTÍNEZ, Doris. La Invención de la Inquisición. Madri: Marcial Pons, 2004, p. 231-305.

${ }^{57}$ Ver o panorama crítico de: MOLINO MARTÍNEZ, Miguel. Historia de la Leyenda Negra Hispanoamericana. Madrid: Marcial Pons, 2004. Ver ainda: THOMAS, Werner. Los Protestantes y la Inquisición en España en tiempos de Reforma y Contrarreforma. Louvain: Presses Universitaires de Louvain, 2001, p. 6-30.

${ }^{58}$ A extensa discussão sobre este tópico pode ser encontrada em: KAMEN, Henry. La Inquisición Española: una revisión histórica. Barcelona: Crítica, 1999; DUFOUR, Gérard. Los orígenes de la historiografía sobre la Inquisición: la obra de Juan Antonio Llorente y su evolución de 1797 a 1817. In: GONZÁLEZ TROYANO, Alberto et alii (Org.). Historia, memoria y ficción: 1750-1850. IX Encuentro de la Ilustración al Romanticismo. Cádiz: Ed. Universidad de Cádiz, 1999, p. 15-22. Para o período medieval, algumas das principais referências são: ARNOLD, John H. Inquisition and Power: catharism and the confessing subject in medieval Languedoc. Philadelphia: University of Pennsylvania Press, 2001; ESCUDERO, José Antonio. Intolerancia e Inquisición. Madrid: Sociedad Estatal de Conmemoraciones Culturales, 2006; FOUCAULT, Michel. A Verdade e as Formas Jurídicas. Rio de Janeiro: EDPUC, 2003; HANAWALT, Barbara ; WALLACE, David (Eds.). Medieval Crime and Social Control. Minneapolis: University of Minnesota Press, 2001; IOGNA-PRAT, Dominique. Ordonner et exclure: Cluny et la societe chretienne face a l'heresie, au judaisme et a l'islam, 1000-1150. Paris: Aubier, 1998; PETERS, Edward. Inquisition... op. cit.; PETERS, Edward. Torture. Oxford: Basil Blackwell, 1985; RICHARDS, Jeffrey. Sexo, Desvio e Danação: as minorias na Idade Média. Rio de Janeiro: Jorge Zahar, 1993. 
da interação social: para o historiador a repressão inquisitorial pressupõe uma sociedade repressora, mais do que algum gênio malévolo. ${ }^{59}$

As engrenagens repressoras da inquisitio devem ser restituídas à ordem social que as abrigava. Este parece um raciocínio elementar, verdadeiramente basilar. Parece, e é só. Pois, nós, historiadores, insistimos em recusá-lo. Quando se trata da "Inquisição", nós persistimos na atitude (ou seria "costume"?) de vislumbrá-la em formato quase absoluto, como um círculo autônomo de poderes, fechado sobre interesses sigilosos, nicho de uma forma toda peculiar de entender o mundo. Fiéis às raízes oitocentistas de nossas ideias, nos agarramos ao hábito de ver as práticas inquisitoriais como atos de uma "Instituição Política". Isto é, como ações de um robusto organismo de poder, diferenciado da sociedade para se tornar impetuosamente eficaz. ${ }^{60} \mathrm{~A}$ "Inquisição Medieval" figura em nossas mentes como um vilão, como o algoz da "correta ordem social", e surge, segundo a sagaz crítica de Alfredo Alvar Ezquerra, como "un instrumento impuesto por no se sabe bien quién contra el 'pueblo', un ente angelical que es siempre el buen salvaje". ${ }^{61}$

Concretamente, isto implica em afirmar que as inquisições medievais não cabem na caracterização de poderes delegados por pontífices. Porém, mais do que a imagem do Papado, o que esta afirmação coloca em debate é o próprio conceito de poder. Em fenômenos como as inquisições, cujas forças e impactos trespassaram estruturas sociais e perduraram por séculos, teriam sido as relações de poder grandezas vetoriais? Puderam ser exercidas unilateralmente? Controladas e apontadas como setas para os conflitos e a interação sociológica? A repressão e a intolerância vivenciadas em larga escala eram efeitos de pontos de efusão do poder, como se ele emanasse de núcleos originários de coerção e de desigualdade? Nas vicissitudes de tempos violentos, o poder foi um "objeto" manipulado somente pelas instituições, que o disparavam contra o conjunto social, ditando sua direção, curso e eficácia?

Se a resposta para perguntas como estas for "sim", então devemos preservar a imagem das inquisições medievais como "criações pontifícias", como instrumentos do "governo dos papas". Entretanto, se a Antropologia Política ${ }^{62}$ e a Nova

\footnotetext{
${ }^{59}$ MOORE, Robert I. La Formación de una... op. cit. Ver igualmente: JOHNSTONE, Nathan. The Devil and Demonism in Early Modern England. Cambridge: Cambridge University Press, 2006, p. 1-59.

${ }^{60}$ SHAPIRO, Ian; SKOWRONEK, Stephen; GALVIN, Daniel (Ed.). Rethinking Political Institutions: the art of the State. Nova York: New York University Press, 2006, p. 1-90.

${ }^{61}$ EZQUERRA, Alfredo Alvar. La Inquisición Española. Madri: Akal, 2009, p. 4.

${ }^{62}$ CLAVERO, Bartolomé. Tantas Personas como Estados: por una antropología política de la historia europea. Madrid: Tecnos, 1986. Ver ainda: CLASTRES, Pierre. A Sociedade contra o
} 
Ciência Política ${ }^{63}$ estiverem corretas ao problematizar o poder como fenômeno intrinsecamente dinâmico e multidirecional, como complexos domínios de tensões sociais, então será preciso - e essa é nossa opinião - deter o passo e repensar o papel do Papado medieval na movente realidade dos poderes inquisitoriais. Não se trata de eximir os governos pontifícios deste passado ou empurrá-los para o fundo de contextos que nos façam perder de vista sua condição de promotores da violência. Tampouco de agraciá-los com uma "lenda branca da Inquisição". Trata-se, mais do que antes, de encará-los como partes dos horizontes maiores de uma história social e política da repressão. Vê-los como integrantes dos processos históricos e não como seus artífices soberanos, senhores dos comportamentos coletivos, instâncias capazes de reger épocas inteiras de cima, do alto de sua alegada autoridade. Em síntese, ações pontifícias como as bulas aqui traduzidas não são autoexplicativas: seus textos não foram declarações fundadoras do que se passou, nem detentores da "lógica essencial" das experiências de intolerância, exclusão e coação que compartilhamos como sociedade por obra da constituição do Ocidente e da própria Cristandade.

Se quebrarmos o encantamento deste olhar que nos remete sempre à imagem de um "self-supporting body" ${ }^{44}$ e explorarmos a constelação das forças sociológicas e políticas que envolviam as ações repressoras, descobriremos cenários históricos dinâmicos, amiúde muito instáveis, quiçá imprevisíveis. Movidos por esta expectativa traduzimos a Ad Abolendam e a Vergentis in Senium e as apresentamos em versão bilíngue, latim-português, pela primeira vez no Brasil: dispostas em versões mais acessíveis, que elas possam fecundar nossa compreensão da história inquisitorial.

Estado. São Paulo: Cosac \& Naify, 2003; CLASTRES, Pierre. Arqueologia da Violência. São Paulo: Cosac \& Naify, 2005; DONOVAN, James M. Legal Anthropology: an introduction. Lanham: AltaMira Press, 2008; KURTZ, Donald V. Political Anthropology: paradigms and power. Cambridge: Westview Press, 2001; LEWELLEN, Ted C. Introducción a la Antropología Política. Barcelona: Bellaterra, 2009; VINCENT, Joan (Ed.). The Anthropology of Politics: a reader in ethnography, theory and critique. Oxford: Blackwell Publishing, 2002.

${ }^{63}$ CHARBY, Annie; CHARBY, Laurent. Le Pouvoir dans touts ses Etats. Paris: Imago, 2003; MCFALLS, Laurent. Construire le politique: contingence, causalité et connaissance dans la Science Politique Contemporaine. Québec: Les Presses de l'Université Laval, 2006; PIERSON, Paul. Politics in Time: history, institutions, and social analysis. Nova Jersey: Princeton University Press, 2004; SFEZ, Lucien (Dir.). Science Politique et Interdisciplinarité. Paris: Publications de la Sorbonne, 2002; TOFFLER, A. Les Nouvaux Pouvoirs: savoir, richesse et violence à la veille du XXI siècle. Paris: L.G.F., 1993; VOEGELIN, Eric. La Nouvelle Science du Politique. Paris: Seuil, 2000.

${ }^{64}$ RAWLINGS, Helen. The Spanish Inquisition. Oxford: Blacwell, 2006, p. 21. 
Leandro Duarte RUST. Bulas Inquisitoriais: Ad Abolendam (1184) e Vergentis in Senium (1199).

\section{4 , novembris 4. Veronae. \\ Lucii III Constitutio Apostolica \\ Bula Ad Abolendam}

Liber Quintus. Ed.: Emil Friedberg. Corpus luris Canonici. Leipzig: Bernhard Tauchnitz, 1881, vol. 2, col. 780-782. Reeditado em Graz: Akademische Druck-U. Verlagsanstalt, 1959.

[1] Ad abolendam diversam haeresium pravitatem, quae in plerisque mundi partibus modernis coepit temporibus pullulare, vigore debet ecclesiasticus excitari, cui nimirum imperialis fortitudinis suffragante potentia, et haereticorum protervitas in ipsis falsitatis suae conatibus elidatur, et catholicae simplicitas veritatis in ecclesia sancta resplendens, eam ubique demonstret ab omni exsecratione falsorum dogmatum expiatam.

[2] Ideoque nos carissimi filii nostri Friderici, illustris Romanorum imperatoris semper Augusti praesentia pariter et vigore suffulti, de communi fratrum nostrorum consilio, nec non aliorum patriarcharum archiepiscoporum multorumque principum, qui de diversis partibus imperii convenerunt, contra ipsos haereticos, quibus diversa capitula diversarum indidit professio falsitatum, praesentis decreti generali sanctione consurgimus, et omnem haeresim, quocumque nomine censeatur, per huius constitutionis seriem auctoritate apostolica condemnamus.
4 de novembro de 1184 . Verona. Constituição Apostólica de Lúcio III. Bula Ad Abolendam

[1] Para abolir a depravação pervertida das heresias que no tempo presente tem começado a pulular em várias partes do mundo, deve-se provocar o eclesiástico com vigor, através do qual, com o auxílio do poder imperial, não só seja esmagada a insolência dos hereges nos próprios esforços de sua falsidade, mas também a simplicidade da verdade católica, resplandecendo na santa igreja, mostre-a por toda parte purificada de toda maldição de falsos dogmas.

[2] Por isso, sustentados com a força de nosso filho caríssimo, Frederico, ilustre imperador dos romanos, sempre augusto, com o habitual conselho de nossos irmãos, [os cardeais], bem como de outros patriarcas, arcebispos e muitos príncipes, que vieram de outras regiões longínquas do império, mediante a promulgação do presente decreto geral, nos erguemos contra os próprios hereges, cuja explicitação de falsidades pervertidas gerou proposições desvirtuadas e, por meio desta constituição, com a autoridade apostólica, condenamos toda a heresia, seja qual for o nome pelo qual é conhecida. 
[3] In primis ergo Catharos et Patarinos et eos, qui se Humiliatos vel Pauperes de Ludguno falso nomine mentiuntur, Passaginos, Iosephinos, Arnaldistas perpetuo decernimus anathemati subiacere.

[4] Et quoniam nonnulli, sub specie pietatis virtutum eius, iuxta quod ait Apostolus, denegantes, auctoritatem sibi vendicant praedicandi: quum idem Apostolus dicat: "quomodo praedicabunt, nisi mittantur?" omnes, qui vel prohibiti, vel non missi, praeter auctoritatem, ab apostolica sede vel ab episcopo loci susceptam, publice vel privatim praedicare praesumpserint.

[5] Et universos, qui de sacramento corporis et sanguinis Domini nostri Iesu Christi, vel de baptismate, seu de peccatorum confessione, matrimonio vel reliquis ecclesiasticis sacramentis aliter sentire aut docere non metuunt, quam sacrosanta Romana ecclesia praedicat et observat, et generaliter, quoscumque eadem Romana ecclesia vel singuli episcopi per dioceses suas cum consilio clericorum, vel clerici ipsi sede vacante cum consilio, si oportuerit, vicinorum episcoporum haereticos iudicaverint, pari vinculo perpetui anathematis innodamus.
[3] Portanto, inicialmente determinamos que Cátaros, Patarinos, aqueles que são designados pelo falso nome de Humilhados ou Pobres de Lyon, Passaginos, Josefinos e Arnaldistas sejam submetidos ao anátema perpétuo.

[4] E porque alguns deles, sob a aparência de piedade e denegrindo a virtude, conforme diz o Apóstolo, reivindicam para si a autoridade para pregar, mesmo quando o mencionado Apóstolo disse "Como pregarão, se não foram enviados?", [condenamos] todos que, proibidos ou não foram enviados, ousaram pregar publicamente ou em privado, sem ter recebido a autoridade da Sé Apostólica ou do bispo do lugar.

[5] E ligamos com o vínculo do anátema perpétuo todos que não temem sentir ou ensinar algo diferente do que a sacrossanta Igreja Romana prega e observa quanto aos sacramentos do Corpo e do Sangue de nosso Senhor Jesus Cristo, do batismo, da confissão dos pecados, do matrimônio ou dos demais sacramentos eclesiásticos. E em geral [ligamos com o mesmo vínculo] quem quer que tenha sido julgado herege pela mesma Igreja Romana ou por cada bispo em sua diocese, aconselhado pelos clérigos, ou pelos próprios clérigos, caso a sé episcopal esteja vacante, e, se for oportuno, aconselhado pelos bispos das dioceses vizinhas. 
[6] Receptores et defensores eorum, cunctosque pariter, qui praedictis haereticis ad fovendam in eis haeresis pravitatem patrocinium praestiterint aliquod vel favorem, sive consolati, sive credentes, sive perfecti, seu quibuscunque superstitiosis nominibus nuncupentur, simili decernimus sententiae subiacere.

[7] Quia vero peccatis exigentibus quandoque contigit, ut severitatis ecclesiasticae disciplinae ab his, qui virtutem eius non intelligunt, contemnatur, praesenti, nihilominus ordinatione sancimus, ut, quicunque manifeste fuerint in haeresi deprehensi, si clericus est vel cuiuslibet religionis obumbratione fucatus, totius ecclesiastici ordinis praerogativa nudetur, et sic omni pariter officio et beneficio spoliatus ecclesiastico, saecularis reliquatur arbitrio potestatis, animadversione debita puniendus, nisi continuo post deprehensionem erroris ad fidei catholicae unitatem sponte recurrere, et errorem suum ad arbitrium episcopi regionis publice consenserit abiurare, et safistationem congruam exhibere. Laicus autem, quem aliqua praedictarum pestium notoria vel privata culpa resperserit, nisi, prout dicutum est, abiurata haeresi et satisfactione exhibita confestim ad fidem confugerit orthodoxam, saecularis iudicis arbitrio reliquantur, debitam recepturus pro qualitate facinoris ultionem.
[6] Também ordenamos que se enquadrem na mesma sentença todos os seus acolhedores e protetores, e todos que, de alguma forma, oferecerem algum apoio ou ajuda aos mencionados hereges, com o propósito de fomentar sobre eles a depravação herética, [e igualmente] os consolados, ou crentes, ou perfeitos ou quaisquer outros nomes supersticiosos pelos quais são chamados.

[7] Posto que, às vezes, na verdade, acontece que a severidade da disciplina eclesiástica contribui em estímulos para o pecado quando é promovida pelos que não compreendem sua virtude, determinamos pela presente ordenação, quanto àqueles que manifestamente foram surpreendidos em heresia, se for clérigo ou se estiver sob a proteção de qualquer ordem religiosa, que seja despojado da prerrogativa de toda ordem eclesiástica, destituído de todo ofício e benefício eclesiástico e entregue ao julgamento do poder secular para ser punido com a pena adequada, exceto se, imediatamente após o erro ter sido descoberto, ele retornar espontaneamente à unidade da fé católica, consentir em abjurar publicamente de seus erros perante o julgamento do bispo local e cumprir com a satisfação correspondente. Por sua vez, o leigo que tiver sido maculado com alguns dos delitos, notórios ou privados, das mencionadas pestes, deve ser conduzido ao julgamento do juiz secular para receber a punição devida à qualidade das más ações, exceto se, conforme foi dito antes, tiver abjurado da heresia e cumprido com a satisfação correspondente, logo que regressou à fé ortodoxa. 
[8] Qui vero inventi sola ecclesiae suspicione notabiles, nisi ad arbitrium episcopi iuxta considerationem suspicionis qualitatemque personae propriam innocentiam congrua purgatione monstraverint, simili sententiae subiacebunt. Illos quosque, qui post abiurationem erroris, vel, postquam se, ut diximus, proprii antistitis examinatione purgaverint, deprehensi fuerint in abiuratam haeresim recidisse, saeculari iudicio sine ulla penitus audentia decernimus relinquendos, bonis damnatorum clericum ecclesiis, quibus deserviebant, secundum sanctiones legitimas applicandis.

[9] Sane praedictam excommunicationis sententiam, cui omnes haereticos praecipimus subiacere, ab omnibus patriarchis, archiepiscopis et episcopis in praecipuis festivitatibus, et quoties solennitates habuerint vel quamlibet occasionem, ad gloriam Dei et reprehensionem haereticae pravitatis decernimus innovari, auctoritate apostolica statuentes, ut, si quis de ordine episcoporum in his negligens fuerit vel desidiosus inventus, per triennale spatium ab episcopali habeatur dignitate et administratione suspensus.
[8] Aqueles descobertos só pela Igreja em evidente suspeita serão submetidos à mesma sentença, exceto se apresentarem ao julgamento do bispo, segundo a consideração da suspeita e a qualidade da pessoa, a própria inocência, por intermédio da reparação adequada. Também aos que, após a abjuração do erro ou, como dissemos, após terem se purificado [dele] mediante o exame do próprio antístite bispo, forem surpreendidos reincidindo na heresia abjurada, determinamos que sejam entregues ao julgamento secular, sem nenhuma outra [possibilidade] de apelação, e que os bens dos condenados sejam entregues ao clérigo das igrejas aos quais serviam, segundo as sanções legítimas a serem aplicadas.

[9] Determinamos que a referida sentença de excomunhão, à qual devem estar submetidos todos os hereges, seja reiterada por todos os patriarcas, arcebispos e bispos nas principais festividades e mantidas em todas as solenidades ou demais ocasiões, para a glória de Deus e a repressão da depravação herética. Se alguém da ordem dos bispos for considerado negligente ou ocioso quanto ao cumprimento desta constituição, por força da autoridade apostólica, ordenamos sua suspensão da dignidade e da administração episcopal pelo espaço de três anos. 
Leandro Duarte RUST. Bulas Inquisitoriais: Ad Abolendam (1184) e Vergentis in Senium (1199).

[10] Ad haec de episcopali consilio et suggestione culminis imperialis et principum eius adiecimus, ut quilibet archiepiscopus vel episcopus per se, vel archidiaconum, suum [sic], aut per alias honestas idoneasque personas, bis vel semel in anno propriam parochiam, in qua fama fuerit haereticos habitare, circumeat, et ibi tres vel plures boni testimonii viros, vel etiam, si expedire videbitur, totam viciniam iurare compellat, quod, si quis ibidem haereticos scierit vel aliquos occulta conventicula celebrantes, seu a communi conversatione fidelium vita et moribus dissidentes, eos episcopo vel archidiacono studeat indicare. Episcopus autem vel archidiaconus ad praesentiam suam convocet accusatos, qui, nisi se ad eorum arbitrium iuxta patriae consuetudinem ab obiecto reatu purgaverint, vel, si post purgationem exhibitam in pristinam relapsi fuerint perfidiam, episcoporum iudicio puniantur. Si qui vero ex eis, iurationem superstitione damnabili respuentes, iurare forte noluerint, ex hoc ipso haeretici iudicentur, et poenis, quae praenominatae sunt, percellantur.
[10] A isto, por conselho dos bispos e recomendação do cume imperial e de seus príncipes, acrescentamos que qualquer arcebispo ou bispo, por si mesmo, ou por seu arquidiácono ou por outras pessoas honestas e idôneas, uma ou duas vezes ao ano, percorra a própria paróquia na qual tenha a notícia de que aí vivem hereges, e aí obrigue a três ou mais homens de bem, ou ainda, se parecer proveitoso, a toda a vizinhança, a jurar que se esforçarão para indicar ao bispo ou ao arquidiácono os que se sabe são hereges ou os que celebram reuniões secretas ou os que se afastam do convívio habitual, da vida e dos costumes dos fiéis. Que o bispo ou o arquidiácono convoque os acusados à sua presença, os quais devem ser punidos segundo o julgamento dos bispos, exceto se tiverem se purificado da acusação imputada mediante o julgamento deles e segundo o costume do lugar ou, se após terem se purificado, forem relapsos reincidindo na perfídia anterior. Se alguns deles, movidos por superstição condenável, recusando o juramento, talvez, se negarem a prestá-lo, que sejam considerados por isto como hereges e submetidos às penas que foram relacionadas acima. 
Leandro Duarte RUST. Bulas Inquisitoriais: Ad Abolendam (1184) e Vergentis in Senium (1199).

[11] Statuimus insuper, ut comites, barones, rectores et consules civitatum et aliorum locorum, iuxta commonitionem archiepiscoporum et episcoporum, praestito corporaliter iuramento promittant, quod in omnibus praedictis fideliter et efficaciter, ab eis exinde fuerint requisiti, ecclesiam contra haereticos et eorum complices adiuvabunt et studebunt bona fide iuxta officium et posse suum ecclesiastica simul et imperiali statuta circa ea, quae diximus, exsecutioni mandare. Si vero id observare noluerint, honore, quem obtinent, spolientur et ad alios nullatenus assumantur, eis nihilominus excommunicatione ligandis, et terris ipsorum interdicto ecclesiae supponendis. Civitas autem, quae his decretalibus institutis duxerit resistendum, vel contra commonitionem episcopi punire neglexerit resistentes, aliarum careat commercio vicitatum et episcopali se noverit dignitate privandam. Omnes etiam fautores haereticorum tanquam perpetua infamia condemnatos, ab advocatione et testimonio et aliis publicis officiis decernimus repellandos. Si qui vero fuerint, qui a lege diocesanae iurisdiciones exempti, soli subiaceant sedis apostolicae potestati, nihilominus in his, quae superius sunt contra haereticos instituta, archiepiscoporum vel episcoporum subeant iudicium, et eis in hac parte, tanquam a sede apostolica delegatis, non obstantibus libertatis suae privilegiis, obsequantur.
[11] Além disso, determinamos que os condes, barões, rectores e cônsules das cidades e de outros lugares, conforme a admoestação dos arcebispos e bispos, mediante juramento prestado pessoalmente, prometam auxiliar fiel e eficazmente a Igreja contra os hereges e seus cúmplices, em tudo que foi [aqui] mencionado, quando forem requisitados; e de boa fé se empenharão em executar todos os estatutos eclesiásticos e imperiais que ditamos, conforme o seu ofício e poder. Mas, se não quiserem observar isto, que sejam destituídos da honra que gozam e de modo algum não obtenham outra e que sejam ligados pela excomunhão e que as terras deles estejam sob o interdito imposto pela Igreja. A cidade que resistir a cumprir estas decretais estabelecidas ou, contrariando a exortação do bispo, negligenciar a punir os que se lhes opõem, estará impedida de comercializar com os vizinhos, saiba que será privada da dignidade episcopal. Também determinamos que todos os partidários dos hereges sejam condenados em infâmia perpétua bem como sejam excluídos da assistência judiciária, de prestar testemunho e de outros ofícios públicos. Entretanto, com base na lei, se houver alguém que esteja isento da jurisdição diocesana, submeta-se apenas ao poder da Sé Apostólica, naquilo que acima foi decretado contra os hereges, todavia, esteja submisso e acate o julgamento dos arcebispos e dos bispos e nesse aspecto, como se fossem delegados da Sé Apostólica, não obstante os privilégios de sua isenção. 
Leandro Duarte RUST. Bulas Inquisitoriais: Ad Abolendam (1184) e Vergentis in Senium (1199).

1199, martii 25. Romae

Innocentii III Litterae Decretales

Bula Vergentis in Senium

Die Register Innocenz' III. 2. Pontifikatsjahr.

2. Pontifiktsjahr 1199-1200. Ed.: O. Hagene-

der, W. Maleczek and A. Strnad.

Roma, 1979, n. 1, p. 3-5

[1] Vergentis in senium saeculi corruptelam non solum sapiunt elementa corrupta, sed etiam dignissima creaturarum ad imaginem et similitudinem condita Creatoris, praelata privilegio dignitatis volucribus coeli et bestiis universae terrae testatur, nec tantum eo quasi deficiente iam deficit, sed et inficit et inficitur scabra rubigine vetustatis. Peccat enim ad extremum homo miserrimus, et, qui non potuit in sui et mundi creatione in paradiso persistere, circa sui et orbis dissolutionem degenerat, et pretii suae redemptionis circa fines saeculorum oblitus, dum variis ac vanis quaestionum se nexibus ingerit, se ipsum laqueis suae fraudis innectit, et incidit in foveam, quam paravit. Ecce etenim, inimico homine messi dominicae superseminante semen iniquum, segetes in zizania pullulant, vel potius polluuntur, triticum arescit, et evanescit in paleas, in flore tinea et vulpes in fructu demoliri vineam Domini moliuntur.

\author{
25 de março de 1199. Roma. \\ Cartas Decretais de Inocêncio III. \\ Bula Vergentis in Senium
}

[1] A corrupção do mundo que avança para a velhice não faz apenas elementos corrompidos exalarem, mas igualmente extingue em um vazio a digníssima reunião dos que foram criados à imagem e à semelhança do Criador, privilégio cuja dignidade superior é testemunhada pelas aves do céu e pelos animais de toda terra, mas que deteriora e é deteriorada pela áspera inação da velhice. De fato, o muito miserável homem peca ao extremo, e quem não pôde, em si e na criação do mundo, permanecer no paraíso, dissemina a dissolução à sua volta e no mundo: esquece o preço de sua redenção levado por razões mundanas, enquanto se deixa envolver com os laços de questões variadas e vãs, ata a si mesmo com os nós de suas fraudes e precipita-se num fosso que ele próprio cava. Eis, com efeito, o rebento iníquo semeando para o inimigo do homem sobre a colheita do Senhor, eis que as searas germinam, ou melhor, são poluídas com cizânia, o trigo seca e evanesce em palhas, a traça e a raposa se põem em ação para destruir a flor e o fruto da vinha do Senhor. 
[2] Nova siquidem sub novo testamento Achor progenies de spoliis Iericho lingulam auream palliolumque furatur, [et] Abyron, Dathan et Chore soboles detestanda novis thuribulis fermentatum thymiama novis volunt altaribus adolere, dum nox nocti scientiam indicat, dum caecus praebet caeco ducatum, dum haereses pullulant, et quem divinae reddit hereditatis expertem, suae constituit haereticus haeresis et damnationis heredem. Hi sunt caupones, qui aquam vino commiscent, et virus draconis in aureo calice Babylonis propinant, habentes, secundum Apostolum, speciem pietatis, virtutem autem eius penitus abnegantes. Licet autem contra vulpes huiusmodi parvulas, species quidem habentes diversas, sed caudas ad invicem colligatas, quia de vanitate conveniunt in id ipsum, diversa praedecessorum nostrorum temporibus emanaverint instituta: nondum tamen usque adeo pestis potuit mortificari mortifera, quin, sicut cancer, amplius serperet in occulto, et iam in aperto suae virus iniquitatis effundat, dum palliata specie religionis et multos decipit simplices, et quosdam seducit astutos, factus magister erroris, qui non fuerat discipulus veritatis.
[2] Portanto, sob o Novo Testamento, a nova prole de Acor rouba a cunha de ouro e o manto, espólios de Jericó; Abirão, Datã e os detestáveis descendentes de Coré desejam adorar novos altares com novos incensos de novos turíbulos, enquanto a noite indica a sabedoria à outra noite, enquanto o cego oferece-se para guiar o cego, enquanto as heresias pululam e quem oferece a herança divina, desprovido dela, se torna herege, herdeiro de sua heresia e condenação. Estes são os taberneiros que misturam água com o vinho e misturam o veneno do dragão no cálice de ouro da Babilônia, conservando, segundo o Apóstolo, aparentando uma espécie de piedade, mas negando por completo a sua virtude. No entanto, contra tais raposinhas que, de fato, possuem diversas aparências, embora todas estejam mutuamente unidas pelas caudas, já que se reúnem levadas pela vaidade deste mesmo propósito, em diferentes ocasiões, inúmeros predecessores nossos tomaram medidas, mas não ao ponto de ter podido aniquilar a peste mortífera, sobretudo contra este câncer que se espalhou amplamente de modo oculto e que, agora, abertamente derrama a iniquidade de seu veneno, enquanto, sob a forma farsesca de religião engana muitos homens simples e seduz alguns astutos, transformando num mestre do erro quem não tinha sido um discípulo da verdade. 
Leandro Duarte RUST. Bulas Inquisitoriais: Ad Abolendam (1184) e Vergentis in Senium (1199).

[3] Ne autem nos, qui, licet circa horam undecimam inter operarios, immo verius super operarios vineae Domini Sabaoth sumus a patrefamilias evangelico deputati, et quibus ex officio pastorali sunt oves Christi commissae, nec capere vulpes demolientes vineam Domini, nec arcere lupos ab ovibus videamur, et ob hoc merito vocari possimus canes muti non valentes latrare, ac perdamur cum malis agricolis et mercenario comparemur: contra defensores, receptatores, fautores et credentes haereticorum aliquid severius duximus statuendum, ut, qui per se ad viam rectitudinis revocari non possunt, in suis tamen defensoribus, receptatoribus et fautoribus, ac etiam credentibus confundantur, et, quum se viderint ab omnibus evitari, reconciliari desiderent omnium unitati.
[3] De fato, nós, que, por assim dizer, por volta da undécima hora, como o pai de família do evangelho, fomos designados para estar entre os lavradores ou, melhor, na verdade, acima dos lavradores das vinhas do Senhor Deus, e a quem, por ofício pastoral, as ovelhas de Cristo foram confiadas, a fim de que não sejamos vistos como incapazes de capturar as raposas que estão destruindo a vinha do Senhor, nem afastar os lobos das ovelhas - e por essa razão poderíamos ser merecidamente chamados de cachorros mudos, incapazes de latir e sermos comparados a maus lavradores e a um mercenário - nós autorizamos medidas um tanto severas contra os defensores, acolhedores, colaboradores e adeptos dos hereges; para que, dessa forma, aqueles que por si não podem ser reconduzidos ao caminho da retidão, sejam, entretanto, confundidos pela condição de seus defensores, acolhedores, colaboradores e adeptos, e quando eles se virem, repelidos por todos, que desejem se reconciliar na unidade de todos. 
[4] De communi ergo fratrum nostrorum consilio, assensu quoque archiepiscoporum et episcoporum apud sedem apostolicam exsistentium, districtius inhibemus, ne quis haereticos receptare quomodolibet vel defensare, aut ipsis favere vel credere quoquo modo praesumat, praesenti decreto firmiter statuentes, ut, si quis aliquid horum facere praesumpserit, nisi primo secundove commonitus a sua super hoc curaverit praesumptione cessare, ipso iure sit factus infamis, nec ad publica officia vel consilia civitatum, nec ad eligendos aliquos ad huiusmodi, nec ad testimonium admittatur. Sit etiam intestabilis, nec ad hereditatis successionem accedat. Nullus praeterea ipsi cogatur super quocunque negotio respondere. Quodsi forte iudex exstiterit, eius sententia nullam obtineat firmitatem, nec causae aliquae ad eius audientiam perferantur. Si fuerit advocatus, eius patrocinium nullatenus admittatur. $\mathrm{Si}$ tabellio, instrumenta confecta per ipsum nullius sint penitus momenti, sed cum auctore damnato damnentur. In similibus etiam idem praecipimus observari. $\mathrm{Si}$ vero clericus fuerit, ab omni officio et beneficio deponatur, ut, in quo maior est culpa, gravior exerceatur vindicta.
[4] Portanto, de acordo com a sugestão consensual de nossos irmãos, [os cardeais], e igualmente, com o assentimento dos arcebispos e bispos presentes nesta Sé Apostólica, proibimos com todo rigor que, de maneira nenhuma, ninguém se atreva, de algum modo, a acolher os hereges, defendê-los, favorecê-los ou apoiá-los; se alguém se atrever a fazer algumas dessas coisas, a não ser que se empenhe em ratificar sua ousadia, após ser avisado pela primeira e segunda vez, mediante este decreto, por força do próprio direito, estabelecemos firmemente que seja considerado infame e não seja aceito para exercer cargos públicos ou tomar parte nos conselhos citadinos ou participar das eleições para tais cargos e tampouco seja admitido como testemunha. Que igualmente seja incompetente para testemunhar nem tenha direito à sucessão hereditária. Ademais, que ninguém seja obrigado a atender-lhe nas obrigações de quaisquer negócios. Caso se trate de um juiz, que sua sentença não tenha valor algum, nem causa alguma seja apresentada ao seu tribunal. Se for advogado, que de modo algum seja aceito para defender. Se for tabelião, que os documentos redigidos por ele careçam de todo efeito e sejam condenados juntamente com seu autor já condenado. Em casos semelhantes, também ordenamos a observância do mesmo [modo de proceder]. Se for clérigo, que seja deposto de todo cargo e benefício, a fim de que naquele em que há maior culpa, sofra uma punição mais severa. 
Leandro Duarte RUST. Bulas Inquisitoriais: Ad Abolendam (1184) e Vergentis in Senium (1199).

[5] Si quis autem tales, postquam ab ecclesia fuerint denotati, contempserit evitare, anathematis se noverit sententiam incurrisse. In terris vero, temporali nostrae iurisdictioni subiectis, bona haereticorum statuimus publicari, et in aliis idem praecipimus fieri per potestates et principes saeculares, quos ad id exsequendum, si forte negligentes exstiterint, per censuram ecclesiasticam appellatione remota compelli volumus et mandamus. Nec ad eos bona eorum ulterius revertantur, nisi eis, ad cor revertentibus et abnegantibus haereticorum consortium, misereri aliquis voluerit, ut temporalis saltem poena corripiat quem spiritualis non corrigit disciplina.
[5] Se alguém desprezar o dever de evitar o contato com tais pessoas, após terem sido declaradas culpadas pela Igreja, saiba que incorre em sentença de anátema. Nas terras submetidas a nossa jurisdição temporal, ordenamos que os bens dos hereges sejam confiscados e nos demais territórios estabelecemos que se faça o mesmo, por intermédio dos poderes e dos príncipes seculares, os quais, acaso se mostrem negligentes em executar essa ordem, queremos e ordenamos que sejam compelidos a cumpri-la, mediante castigos eclesiásticos, sem haver possibilidade de apelação. Que não sejam, posteriormente, devolvidos a tais hereges os seus bens, a não ser que alguém queira usar de misericórdia para com os que tiverem se convertido de coração e renegado a companhia dos hereges, para que, ao menos, o castigo temporal puna o que não se corrige por força das punições espirituais. 
[6] Quum enim secundum legitimas sanctiones, reis laesae maiestates punitis capite, bona confiscentur eorum, filiis suis vita solummodo ex misericordia conservata: quanto magis, qui aberrantes in fide Domini Dei filium Iesum Christum offendunt, a capite nostro, quod est Christus, ecclesiastica debeat districtione praecidi, et bonis temporalibus spoliari, quum longe sit gravius aeternam quam temporalem laedere maiestatem? Nec huiusmodi severitatis censuram orthodoxorum etiam exheredati filiorum quasi cuiusdam miserationis praetextu debet ullatenus impedire, quum in multis casibus etiam secundum divinum iudicium filii pro patribus temporaliter puniantur, et iuxta canonicas sanctiones quandoque feratur ultio non solum in auctores scelerum, sed etiam in progeniem damnatorum.
[6] Quanto aos culpados pelo delito de lesa-majestade, que sejam punidos, em conformidade com os castigos legais, isto é, seus bens sejam confiscados, e que a vida de seus filhos seja poupada somente por misericórdia: ora, quanto mais os que se distanciam da fé no Senhor, ofendendo a Jesus Cristo, Filho de Deus, sejam separados de nossa cabeça, Cristo, por sentença eclesiástica, e despojados de bens temporais, pois não é mais grave ofender a majestade eterna do que a temporal? Nem de modo algum seja impedida [a aplicação] do rigor deste castigo dos ortodoxos, sob o pretexto de certa aparência de misericórdia no tocante aos filhos daquele que perdeu seus bens, pois, segundo o julgamento divino, em muitas circunstâncias, também estes sofrem temporalmente por causa de seus pais e, conforme as penas canônicas, algumas vezes, o castigo recai não apenas sobre os criminosos, mas também sobre a descendência dos que foram condenados. 